\title{
Spatio-temporal Variations of Tropospheric Nitrogen Dioxide in Turkey Based on Satellite Remote Sensing
}

\author{
Doğukan Doğu YavaşlıA \\ Received: February 29, 2020 | Revised: May 14, 2020 | Accepted: May 25, 2020 \\ doi: 10.5937/gp24-25482
}

\begin{abstract}
The satellite observations of $\mathrm{NO}_{2}$ acquire the total tropospheric column over an area while the current ground observations lack spatial and temporal coverage. In this study the Dutch Ozone Monitoring Instrument (OMI) NO2 (DOMINO) data product v2.0 for 2004 - 2019 period was used to analyze the spatial and temporal variations of $\mathrm{NO}_{2}$ in Turkey. Considering the seasonality characteristics of $\mathrm{NO}_{2}$, we have used pixel based Seasonal Kendall (S-K) test to investigate the trend of the change. The highest values of $\mathrm{NO}_{2}$ has been found at the metropolitan areas and perimeter of the high capacity power plants in the observed period. The monthly average concentrations of $\mathrm{NO}_{2}$ are higher in winter months due to the higher demand of heating and power usage. The $\mathrm{S}-\mathrm{K}$ trend test results indicate a statistically negative trend at the largest cities such as Istanbul, Ankara and Izmir. However statistically significant positive trend has been found in some areas and Syrian border provinces in particular. Our results show that there is an abrupt change by 2011 in the tropospheric NO2 concentrations, same period when the first Syrian refugees have arrived after the political disorder. The dramatic change at the emission landscape of the $\mathrm{NO}_{2}$ in the region can be explained by changes in population concentration due to political circumstances.
\end{abstract}

Keywords: $\mathrm{NO}_{2}$; OMI; DOMINO data; Seasonal Kendall; Turkey

\section{Introduction}

Nitrogen oxides $\left(\mathrm{NO}_{\mathrm{X}}\right)$ (nitrogen monoxide and nitrogen dioxide) forms at high temperatures that can cause molecular nitrogen in the atmosphere to react with oxygen. At room temperatures nitrogen and oxygen do not react each other. Therefore, formation of $\mathrm{NO}_{\mathrm{X}}$ can originate naturally from lightning strikes and forest fires or with anthropogenic activities such as burning fossil fuels at high temperatures. Large amounts of $\mathrm{NO}_{\mathrm{X}}$ are produced by anthropogenic activities firstly in the form of NO, then it is rapidly transformed in to $\mathrm{NO}_{2}$ by reaction with ozone (Castellanos \& Boersma, 2012). The total global anthropogenic emissions of $\mathrm{NO}_{\mathrm{X}}$ are roughly $122 \mathrm{Mt} /$ year however due to short atmospheric lifetime (approximately hours) the concentrations are highly variable in time and space (Crippa et al., 2018).

The effects of high $\mathrm{NO}_{2}$ levels to health mainly consists of respiratory problems such as coughing, difficulty in breathing, wheezing, colds, flu and bronchitis that makes $\mathrm{NO}_{2}$ is one of the primary pollutants. On the other hand, $\mathrm{NO}_{2}$ provides a contributing component for secondary pollutants by forming ozone $\left(\mathrm{O}_{3}\right)$ with releasing oxygen atoms when exposed to sunlight (Kharol et al., 2015).

The measurement of atmospheric $\mathrm{NO}_{2}$ is traditionally established with ground station data. However, air quality stations lack of temporal and spatial coverage, particularly in developing countries such as Tur-

\footnotetext{
A Kırşehir Ahi Evran University, Department of Geography, Kırşehir, TURKEY; dogukan.yavasli@ahievran.edu.tr
} 
key. Conversely, remote sensing data provide data for areas without a ground station and more importantly has retrospective view.

The satellite observations of $\mathrm{NO}_{2}$ acquire the total tropospheric column over an area whereas air quality stations measure its concentration near the ground. Leaving aside lightnings and air transportation, the major sources of $\mathrm{NO}_{2}$ is located at the land surface and therefore the $\mathrm{NO}_{2}$ detected by satellites mostly originate from atmospheric boundary layer (Richter et al, 2005).

The first monitoring of $\mathrm{NO}_{2}$ at troposphere have started with Global Ozone Monitoring Experiment (GOME) on European Remote-Sensing Satellite-2 (ERS-2) satellite in 1995 and it continued with SCanning Imaging Absorption spectroMeter for Atmospheric CHartographY (SCIAMACHY) in 2002, Ozone Monitoring Instrument (OMI) aboard Aura satellite in 2004, GOME-2 in 2007 and TROPOspheric Monitoring Instrument (TROPOMI) on board the Copernicus Sentinel-5 Precursor satellite in 2017. Among these, OMI has been observing the atmospheric $\mathrm{NO}_{2}$ daily since late 2004 at spatial resolution of $13 \times 24 \mathrm{~km}$ at nadir view increasing in size to $24 \times 135$ $\mathrm{km}$ for largest view angles.

Recently, various studies have been carried out on the satellite observations of tropospheric $\mathrm{NO}_{2}$ columns. For instance, Richter et al. (2005) presented the tropospheric column amounts of $\mathrm{NO}_{2}$ obtained from GOME and SCIAMACHY for the period 1996-2004. They have found a significant decrease in Europe and USA with a 50\% increase in the industrial areas of China. The $\mathrm{NO}_{2}$ concentration decrease in Europe has also been noted by Castellanos and Boersma (2012) between the years 2004 and 2010. Their regres- sion models show that most of the metropolitan areas in Europe have a decrease around 20\% according to the OMI satellite data. The increase in tropospheric $\mathrm{NO}_{2}$ concentrations in China has also been noted by Schneider and Van Der A (2012). Their calculations of SCIAMACHY data indicate that the trend in China is between $4-19.7 \times 10^{15}$ molecules $/ \mathrm{cm}^{2}$ per year and there is a strong agreement of $\mathrm{NO}_{2}$ concentrations at Europe and USA. On the other hand, a more recent study has found that there is a $6 \%$ decrease at $\mathrm{NO}_{2}$ level at China after 2011 according to the OMI data (Irie et al., 2016). Similar results have been found by Cai et al. (2018) for Chengdu-Chongqing Economic Zone in China. Their results indicate high $\mathrm{NO}_{2}$ concentrations in the northwest of Chengdu and southeast of Chongqing with an inflection point towards a decrease in the year 2011. The change in the tropospheric $\mathrm{NO}_{2}$ can sometimes be abrupt. For instance, Lelieveld et al. (2015) have found that economic crisis and armed conflicts have urgently shifted the $\mathrm{NO}_{2}$ emissions in the Middle East. These studies have shown that tropospheric $\mathrm{NO}_{2}$ concentrations are not only controlled by emission policies to improve air quality but also economic, industrial and other human controlled activities.

Although there are various inventories at global and regional scale and they commonly use regression models for trend analysis, the examination of the trends of the tropospheric $\mathrm{NO}_{2}$ has never been made for Turkey. Here, we analyze the tropospheric $\mathrm{NO}_{2}$ over Turkey for the period 2004-2019 using OMI data. We present the spatial distribution characteristics of $\mathrm{NO}_{2}$ as well as the temporal change over time by a novel approach of using Seasonal Kendall test for each pixel.

\section{Materials and Methods}

The DOMINO v2.0 dataset of European Space Agency (ESA) Tropospheric Emission Monitoring Internet Service (TEMIS; www.temis.nl) based on the OMI orbits has been used in this study. DOMINO is a postprocessing level 2 data set of OMI, providing geophysical information for each ground pixel observed by the instrument. The $\mathrm{NO}_{2}$ retrieval algorithm of DOMINO dataset consists of three stages: using Differential Optical Absorption Spectroscopy (DOAS) to obtain $\mathrm{NO}_{2}$ slant columns from the OMI reflectance spectra, separating the stratospheric and tropospheric contribution to the slant column and converting the tropospheric slant column to a vertical column with the tropospheric air mass factor (AMF) (Boersma et al., 2011). Monthly averages as a unit of $10^{13}$ molecules/ $\mathrm{cm}_{2}$ have obtained from TEMIS and converted to $10^{15}$ molecules $/ \mathrm{cm}^{2}$. The data is filtered with $30 \%$ cloud radiance fraction. The dataset includes October $2004-$ October 2019 period. The annual averages have been calculated using 12-month calendar year data. The monthly, seasonal and whole period averages have been used to acquire the spatial, annual and seasonal cycle of tropospheric $\mathrm{NO}_{2}$ concentrations.

The temporal change of $\mathrm{NO}_{2}$ at the study area has been investigated through seasonal Kendall (S-K) test. The S-K test is a modified case of Mann-Kendall trend test to analyze data for monotonic trends in seasonal data (Mann, 1945; Kendall, 1975; Hirsch et al., 1982). The seasonality refers that the data have variable distributions for different seasons or months of the year.

We have tested each pixel at the study area by two hypotheses with $\mathrm{S}-\mathrm{K}$ : the $\mathrm{H}_{\mathrm{o}}$, hypothesis regarding 
there is no trend in the time series and the alternative $\mathrm{H}_{\mathrm{a}}$ hypothesis that there is a statistically significant negative or positive trend in the series at 0.01 and 0.05 significance level. The Kendall tau coefficient $(\tau)$ has been used to identify rank correlation where the positive $\tau$ value indicates an increasing trend as well as a low negative value is an indicator of a decreasing one. The estimate of the trend slope over time has been computed using a generalized version of the Sen slope estimator (Sen, 1968).

We have also used Pettitt's test to the selected areas to test the homogeneity and identify the time when a shift occurs. This test hypothesize that values are independent and identically normally distributed in the null hypothesis and the alternative one assumes that the series has a shift in a given time (Pettitt, 1979).

\section{Results and Discussion}

\section{Spatial Distribution of $\mathrm{NO}_{2}$}

Figure 1 gives the overview of the average distributions of the tropospheric $\mathrm{NO}_{2}$ concentration from 2004 to 2019 over Turkey. The highest concentrations are observed at the most populated and industrialized cities such as Istanbul, Ankara, Izmir, Bursa and Adana as expected. The $\mathrm{NO}_{2}$ concentrations reach $7 \times 10^{15}$ molecules $/ \mathrm{cm}^{2}$ at Istanbul, the industrialization and urbanization center of Turkey with more than 15 million inhabitants. Other $\mathrm{NO}_{2}$ hotspots are northern $\mathrm{K}$. Maraş, northwestern Manisa, western Muğla, central Konya and southern Şırnak. These hotspots have coalfired power plants (Fig. 2).

The $\mathrm{NO}_{2}$ concentrations in Turkey show large seasonal amplitude with highest values in November, December, January and February and lowest values June, July August (fig. 3). It is well known that because of the excessive use of powerplants and home heating, $\mathrm{NO}_{2}$ levels increase in northern hemisphere winter months. This seasonal characteristics about the distribution of $\mathrm{NO}_{2}$ also arise from the hydroxyl radical $(\mathrm{OH})$ and the photolysis frequency of $\mathrm{NO}_{2}$. Higher winter val- ues are usually associated with the decreasing loss of $\mathrm{NO}_{2}$ by reaction with $\mathrm{OH}$ which is the major $\mathrm{NO}_{\mathrm{X}}$ loss process in the lower troposphere. A lower photolysis rate is observed in winter the northern hemisphere that depletes $\mathrm{NO}_{2}$ due to less sunlight (Xiao et al., 2013). Therefore, in the winter months with less sunlight, $\mathrm{NO}_{2}$ is removed more slowly from the atmosphere (Saini et al., 2008). The high $\mathrm{NO}_{2}$ levels in winter is usually associated with anthropogenic activities being the dominant $\mathrm{NO}_{2}$ source rather than biomass burning or soil emissions (Van Der A et al., 2008).

\section{Temporal Distribution of $\mathrm{NO}_{2}$}

Examining the annual averages of $\mathrm{NO}_{2}$ over Turkey for 2004-2019 period (fig. 4) there are peaks and decreases for various areas in Turkey. In general, the effects of 2008 global economic crisis can be observed between 2009-2011 period in most of the provinces primarily in Istanbul, Ankara and Izmir which can be associated with the decrease in industrial production. This is consistent with Castellanos and Boersma’s (2012) results. Same decrease can also be noticed

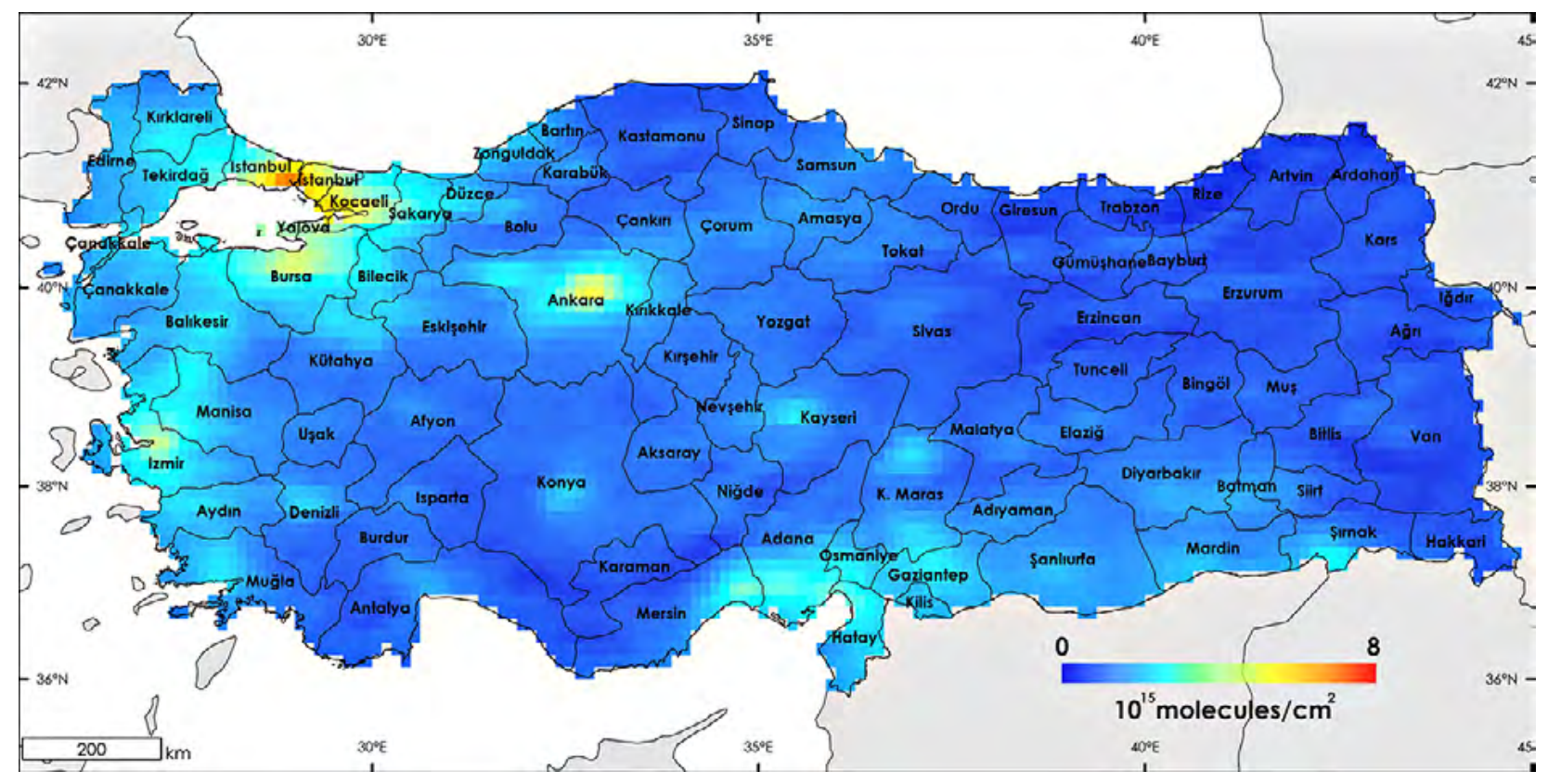

Figure 1. The mean annual tropospheric $\mathrm{NO}_{2}$ over Turkey for the period $2004-2019$ 


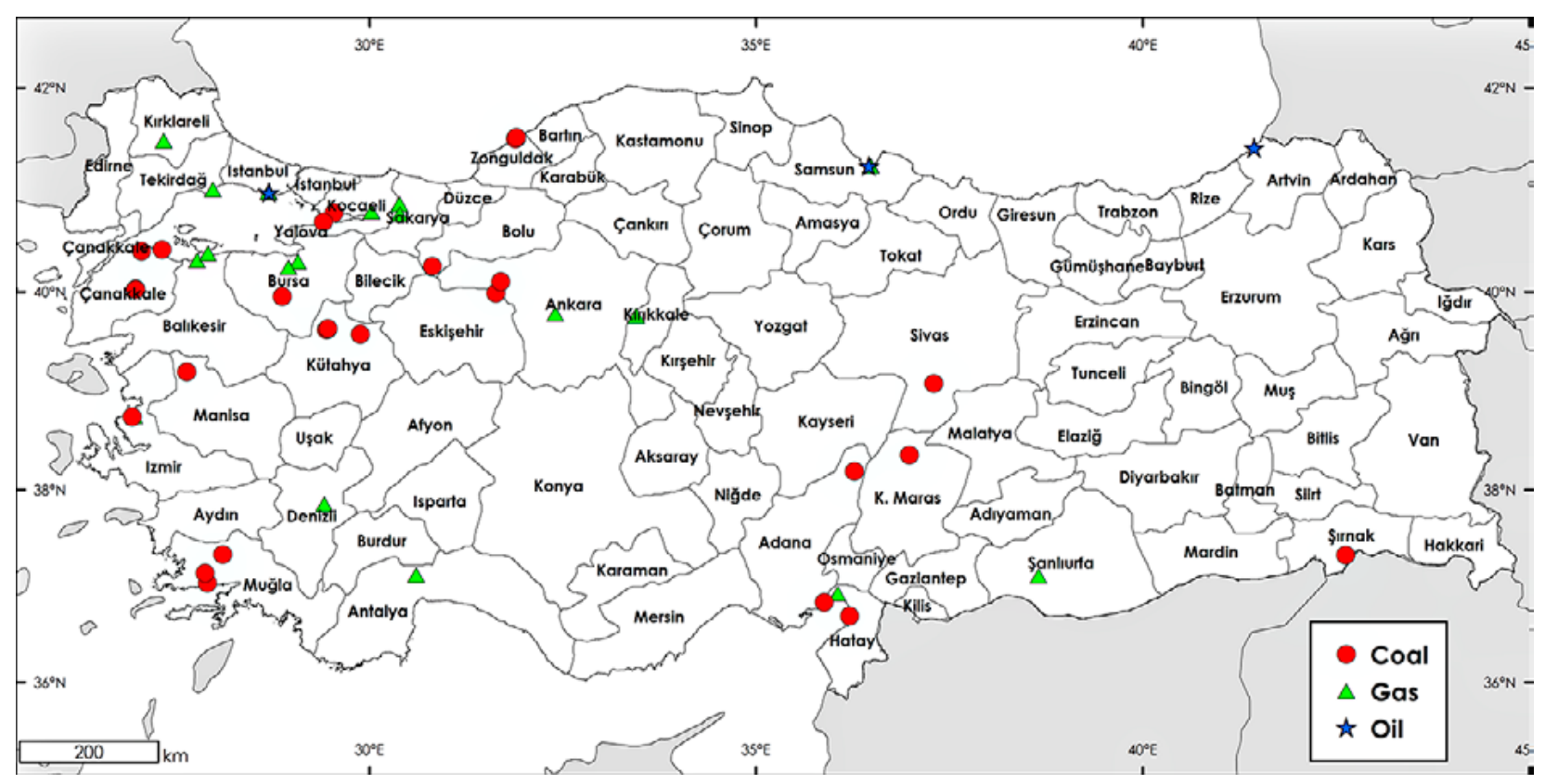

Figure 2. The power plants of Turkey Source: WRI, 2019

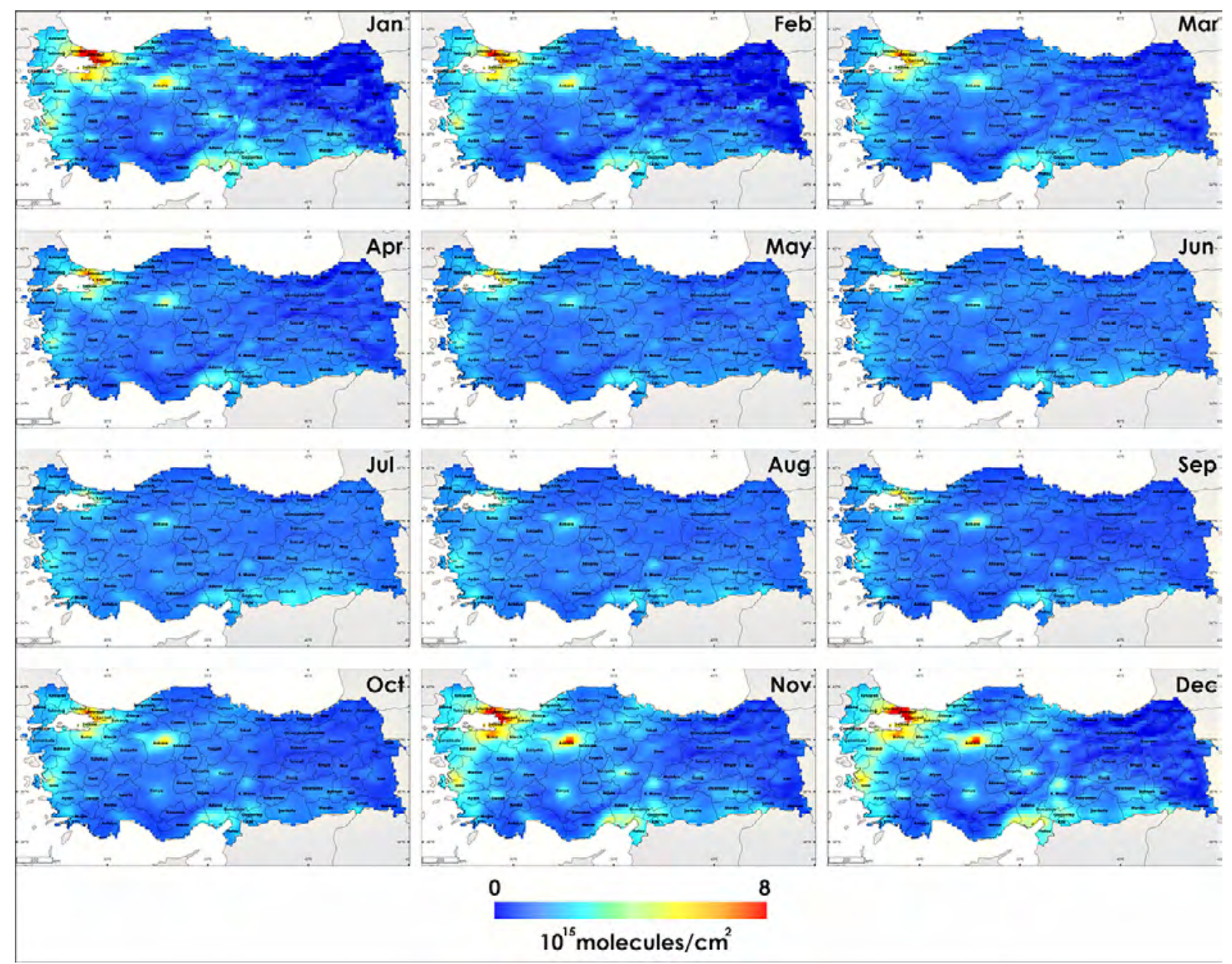

Figure 3. The mean monthly values of tropospheric $\mathrm{NO}_{2}$ over Turkey for the period $2004-2019$ 


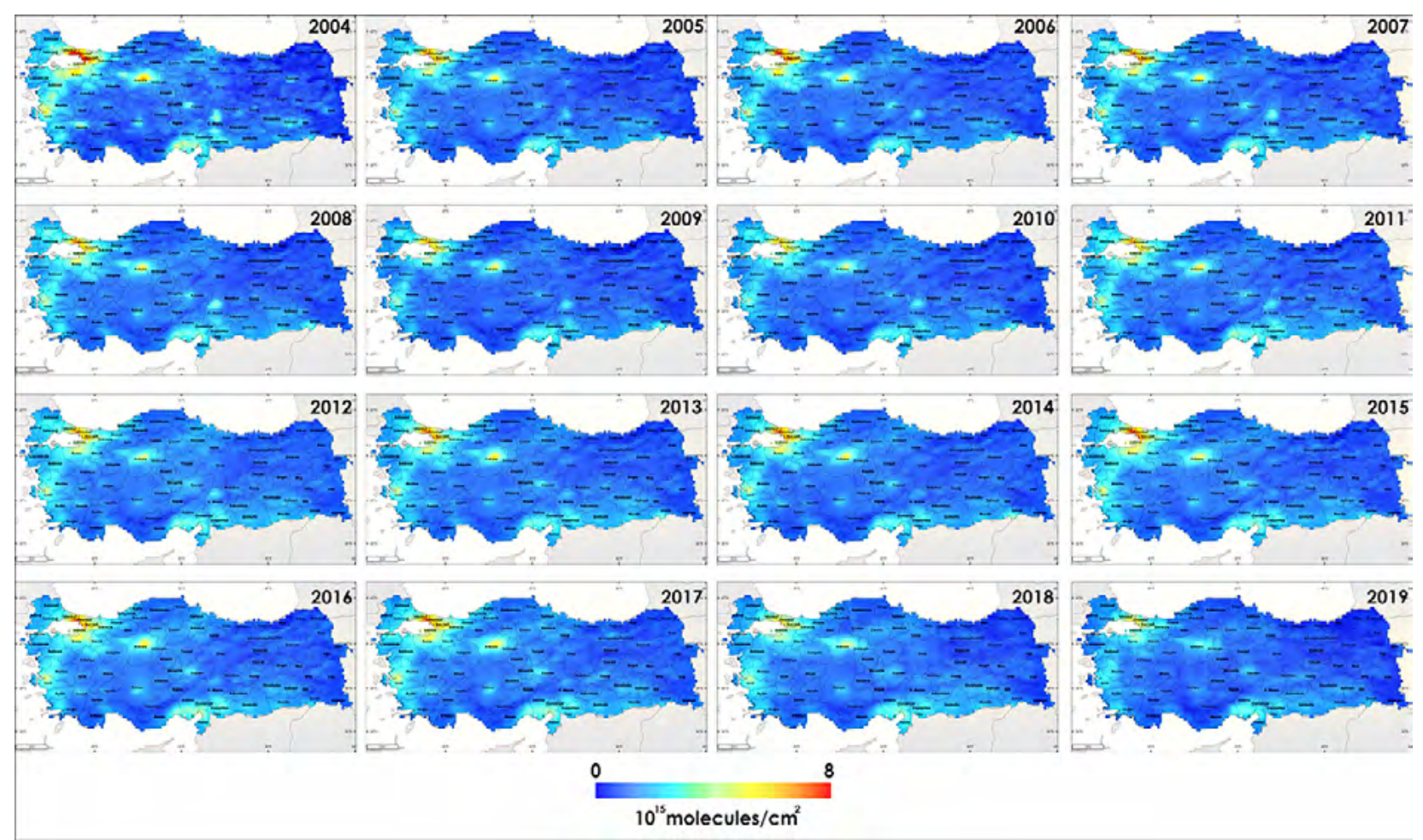

Figure 4. Yearly averages of tropospheric $\mathrm{NO}_{2}$ over Turkey for the period $2004-2019$ (please note that the years 2004 and 2009 does not have 12-month data)

at the areas with large fossil fuel power plants such as K. Maraş.

The temporal change of the tropospheric $\mathrm{NO}_{2}$ has been evaluated using S-K test. Figure 5 shows the $\tau$ values as a means to assess the significance of the crosscorrelation between the time series and $\mathrm{NO}_{2}$ concentrations whereas the significance levels of the trends can be examined in figure 6 . The highest values of $\tau$ is observed particularly at the south provinces of Turkey such as Gaziantep, Şanlıurfa, Kilis referring an increase for $\mathrm{NO}_{2}$ concentrations. Other high values can be noticed at individual areas such as eastern Sakarya, northern Kırıkkale, southeastern İzmir and northern Çanakkale. These results are statistically significant at $99 \%$ level with a positive trend of $0.08 \times 10^{15}$ molecules/ $\mathrm{cm}^{2} /$ year according to the $\mathrm{p}$-values and Sen's slope calculations (Fig. 6 and Fig. 7).

When considered from this point of view, the positive trend at the Syrian border provinces (Gaziantep, Şanlıurfa and Kilis) is remarkable. The change $\mathrm{NO}_{2}$ concentrations in the region have increased $1.2 \times 10^{15}$ molecules $/ \mathrm{cm}^{2}$ in the 15 -year period. In order to un- veil the reasons for this change and the exact time of the change, we have applied Pettitt's test to the pixel values at these provinces. The test results indicate that $94 \%$ of these pixels have a significant change point (or a shift) exists and $79 \%$ of it indicates an abrupt change on May 2011. Considering the start of the revolt in Syria in March 2011, the first Syrian refugees have arrived in Turkey on $29^{\text {th }}$ April 2011 (Özden, 2013; Özdemir, 2017). The number of the Syrian refugees were $33,818,37,385$ and 67,753 in 2013 at Gaziantep, Kilis and Şanliurfa respectively. These numbers have changed to $452,419,115,599$ and 430,049 in 2019 following the same order (table 1) (Directorate General for Migration Management, 2019). Therefore, we attribute the significant positive trend for tropospheric $\mathrm{NO}_{2}$ in this region to the Syrian refugee influx started in 2011 and correspondingly the increasing number of inhabitants as well as increasing anthropogenic activities. It should be noted that the refugees typically use coal burning stoves since the government and nongovernmental organizations provide coal (Leghtas \& Hollingsworth, 2017). Considering the percentage of

Table 1. The population change and the number of Syrian refugees in selected cities.

\begin{tabular}{|l|r|r|r|r|}
\hline & Population (2004) & Population (2018) & Syrian Refugee (2019) & $\begin{array}{c}\text { Percentage of the Refugees to } \\
\text { 2018 Population }\end{array}$ \\
\hline Gaziantep & $1,441,079$ & $2,028,563$ & 452,419 & $22 \%$ \\
\hline Kilis & 114,615 & 142,541 & 115,599 & $81 \%$ \\
\hline Şanlıurfa & $1,404,961$ & $2,035,809$ & 430,049 & $21 \%$ \\
\hline
\end{tabular}


the number of refugees to the population, the increase at Kilis province is more evident.

On the other hand, low $\tau$ values can be observed at western Thracian provinces such as Tekirdağ, Kirklareli, Edirne as well as northeastern part of Turkey. Istanbul, Ankara, Izmir, Bursa as the four most populous cities have also negative $\tau$ values referring a negative trend for the $\mathrm{NO}_{2}$ concentrations. The negative trend can be noticed also at northern K. Maraş and southern
Şırnak where the Afşin-Elbistan and Silopi coal-fired power plants are located respectively (fig. 2). This negative trend is statistically significant at $99 \%$ level with a Sen's slope value of $-0.08 \times 10^{15}$ molecules $/ \mathrm{cm}^{2}$ year ${ }^{-1}$ (fig. 6 and fig. 7). The negative trend can be associated with 2008-2009 global economic recession for the large cities and emission controls for the ones with large power plants (Castellanos \& Boersma, 2012; Ministry of Environment and Urban Planning, 2009).

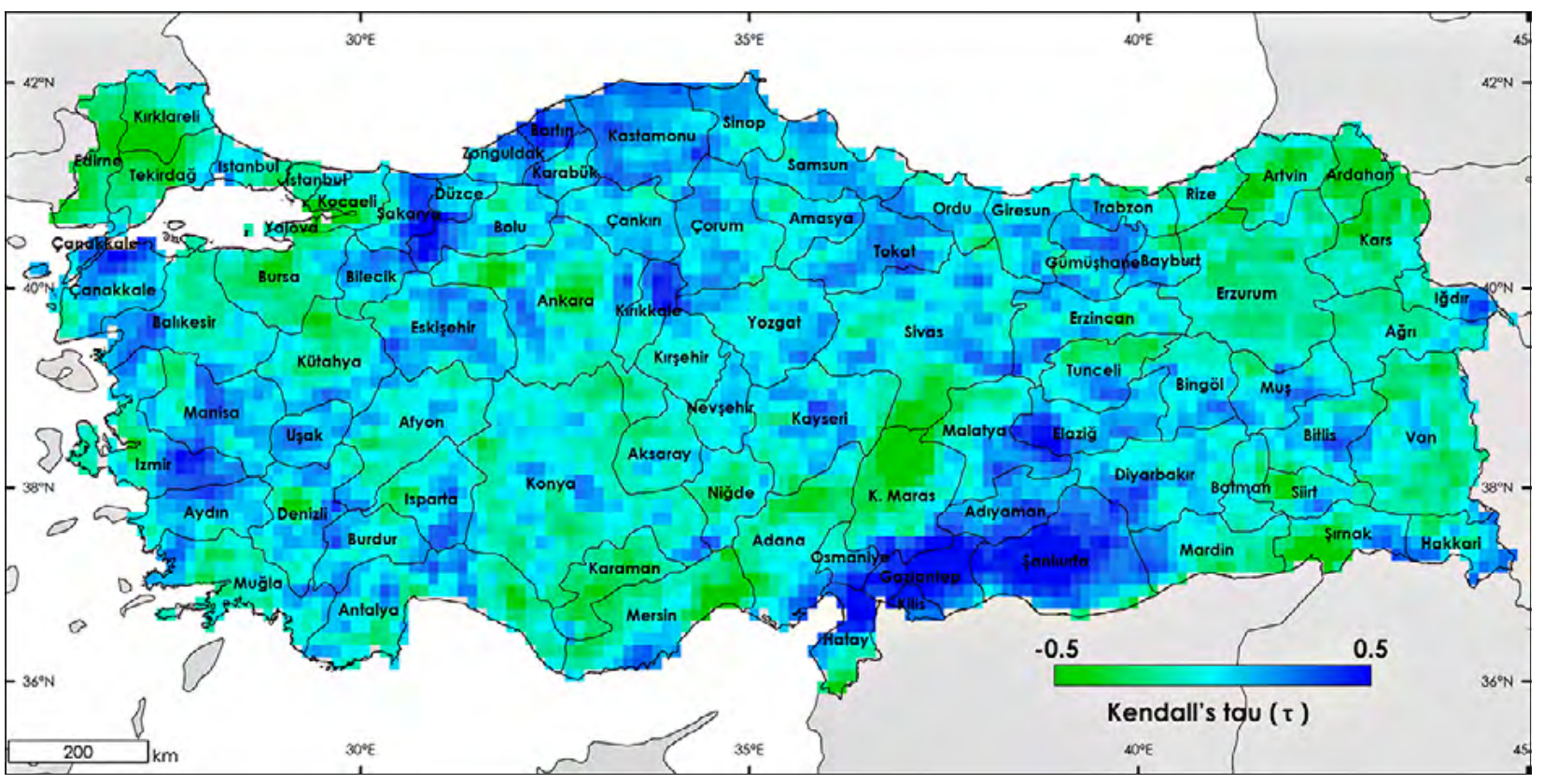

Figure 5. Kendall's tau $(\tau)$ values of S-K test

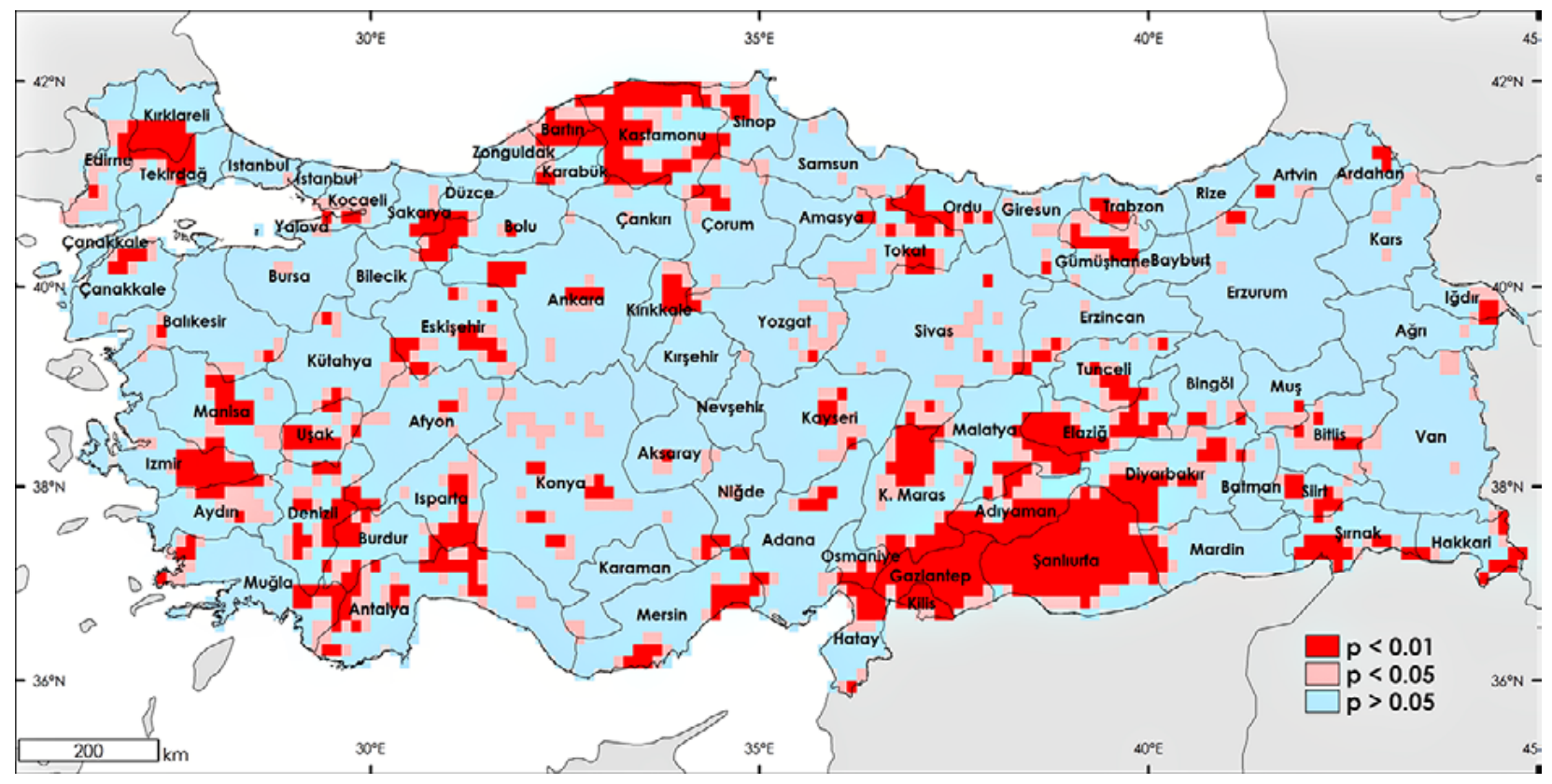

Figure 6. Significance level of the trends 


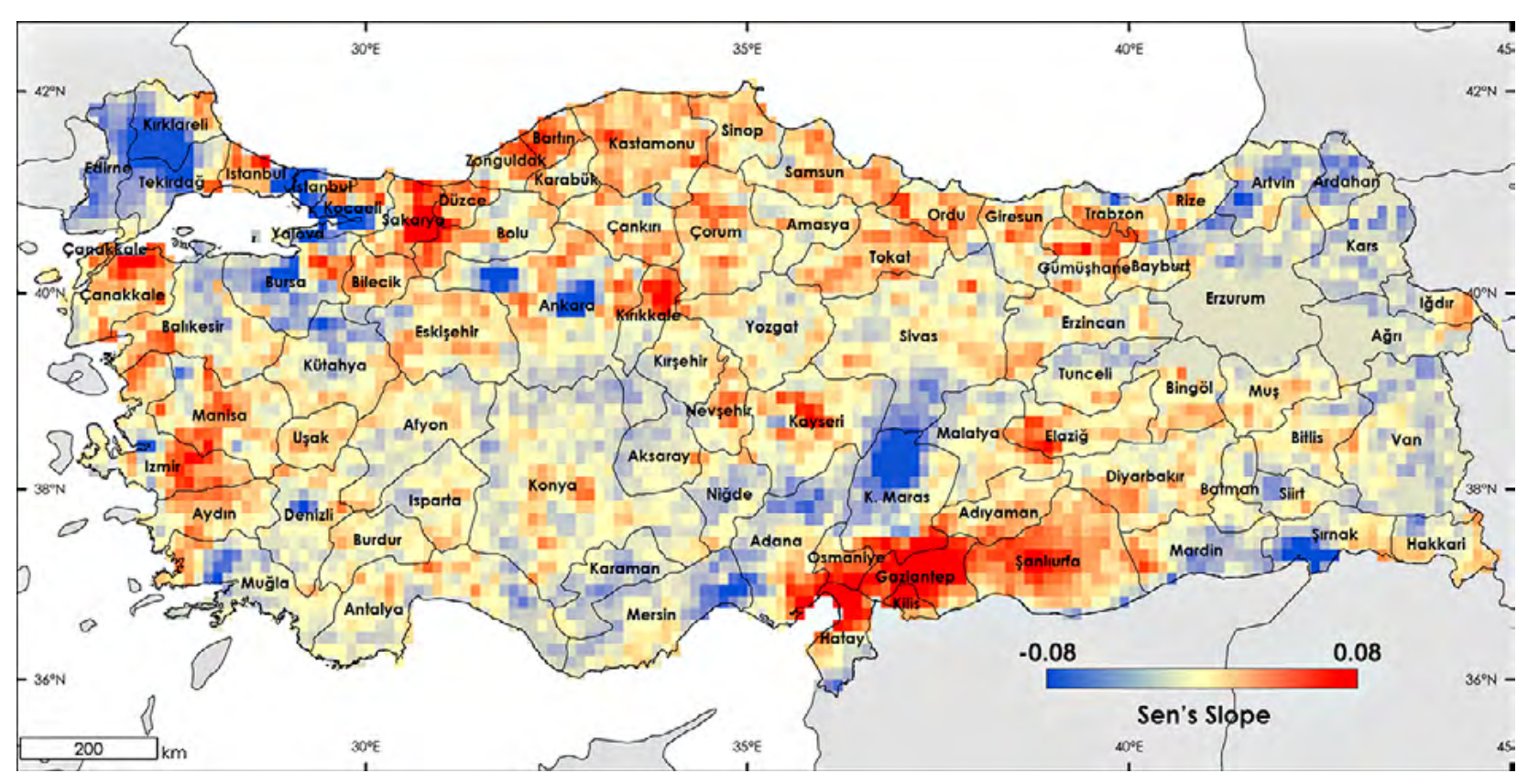

Figure 7. Sen's slope values

\section{Conclusions}

Using monthly tropospheric $\mathrm{NO}_{2}$ column observations from OMI, we were able to present spatio-temporal multi-year changes in $\mathrm{NO}_{2}$ at Turkey. Considering its seasonality this study analyzed the spatio-temporal distribution in Turkey for a 15-year period with S-K analysis.

The largest cities such as Istanbul, Ankara, Izmir, Bursa and Adana have highest levels of $\mathrm{NO}_{2}$ in a consequence of anthropogenic activities. Other main sources of $\mathrm{NO}_{2}$ are mostly located around high capacity powerplants. Regarding the annual cycle of $\mathrm{NO}_{2}$, the levels are higher in winter months and lower on summers.

The overview of tropospheric $\mathrm{NO}_{2}$ concentrations during the period $2004-2019$ reveals large changes in Turkey. Most of the large cities and the surround- ings of some power plants have a negative trend according to the S-K analysis. On the other hand, the statistically positive trends are mostly observed at the Syrian border provinces such as Gaziantep, Kilis and Şanlıurfa. This has been attributed to the increasing refugee numbers and anthropogenic activities at these provinces after 2011. The Pettitt's test results for the region indicate similar period for an abrupt change.

Since the satellite data offer global coverage, the method used in this study to analyze the observation time series considering its seasonal pattern, can be applied to any region worldwide. The ongoing and planned observations of tropospheric $\mathrm{NO}_{2}$ with satellites will provide a better understanding of our $\mathrm{NO}_{2}$ emissions and their spatio-temporal distribution.

\section{Acknowledgments}

We would like to acknowledge the use of the tropospheric $\mathrm{NO}_{2}$ column data from http://www.temis.nl, and we are grateful to E. Erlat for reviewing the earlier draft.

\section{References}

Boersma, K. F., Eskes, H. J., Dirksen, R. J., van der A, R. J. J., Veefkind, P., Stammes, P., Huijnen V., Kleipool Q. L., Sneep M., Claas J., Leitão J., Richter A., Zhou Y. \& Brunner D. (2011). An improved retrieval of tropospheric $\mathrm{NO}_{2}$ columns from the
Ozone Monitoring Instrument. Atmospheric Measurement Techniques, 4, 1905-1928.

Cai, K., Zhang, Q., Li, S., Li, Y., \& Ge, W. (2018). Spatial-Temporal Variations in $\mathrm{NO}_{2}$ and $\mathrm{PM}_{2} .5$ over the Chengdu-Chongqing Economic Zone in China 
during 2005-2015 Based on Satellite Remote Sensing. Sensors, 18(11), 3950.

Castellanos, P., \& Boersma, K. F. (2012). Reductions in nitrogen oxides over Europe driven by environmental policy and economic recession. Scientific Reports, 2, 265.

Crippa, M., Guizzardi, D., Muntean, M., Schaaf, E., Dentener, F., van Aardenne, J. A., Monni S., Doering U., Olivier J. G. J., Pagliari V. \& Janssens-Maenhout, G. (2018). Gridded emissions of air pollutants for the period 1970-2012 within EDGAR v4. 3.2. Earth System Science Data, 10(4), 1987-2013.

Directorate General for Migration Management (2019) https://en.goc.gov.tr/, last access (December 2019)

Hirsch, R. M., Slack, J. R., \& Smith, R. A. (1982). Techniques of trend analysis for monthly water quality data. Water Resources Research, 18(1), 107-121.

Irie, H., Muto, T., Itahashi, S., Kurokawa, J. I., \& Uno, I. (2016). Turnaround of tropospheric nitrogen dioxide pollution trends in China, Japan, and South Korea. Sola, 12, 170-174.

Kendall, M. G. (1975). Rank Correlation Methods. Griffin, London, UK.

Kharol, S. K., Martin, R. V., Philip, S., Boys, B., Lamsal, L. N., Jerrett, M., Brauer M., Crouse D.L., McLinden C. \& Burnett, R. T. (2015). Assessment of the magnitude and recent trends in satellite-derived ground-level nitrogen dioxide over North America. Atmospheric Environment, 118, 236-245.

Leghtas I. \& Hollingsworth A. (2017) "I am only looking for my rights" - Legal employment still inaccessible to refugees in Turkey, Refugees International Report.

Lelieveld, J., Beirle, S., Hörmann, C., Stenchikov, G., \& Wagner, T. (2015). Abrupt recent trend changes in atmospheric nitrogen dioxide over the Middle East. Science Advances, 1(7), e1500498.

Mann, H. B. (1945). Nonparametric tests against trend. Econometrica: Journal of the Econometric Society, 245-259.

Ministry of Environment and Urban Planning. (2009). Regulation on the control of industrial air pollu- tion Turkey, https://cygm.csb.gov.tr/yonetmelikleri-440, last access (January 2020).

Özdemir, E. (2017). Suriyeli Mülteciler Krizinin Türkiye'ye Etkileri. Uluslararası Kriz ve Siyaset Araştırmaları Dergisi, 1(3), 114-140. (in Turkish with English summary)

Özden, S. (2013). Syrian refugees in Turkey. Migration Policy Centre, MPC Research Report, 2013/05.

Pettitt, A. N. (1979). A non-parametric approach to the change-point problem. Journal of the Royal Statistical Society: Series C (Applied Statistics), 28(2), 126135.

Richter, A., Burrows, J. P., Nüß, H., Granier, C., \& Niemeier, U. (2005). Increase in tropospheric nitrogen dioxide over China observed from space. Nature, 437(7055), 129.

Saini, R., Satsangi, G. S., \& Taneja, A. (2008). Concentrations of surface $\mathrm{O}_{3}, \mathrm{NO}_{2}$ and $\mathrm{CO}$ during winter seasons at a semi-arid region-Agra, India. Indian Journal of Radio \& Space Physics, 37(2), 121-130.

Schneider, P., \& van der A, R. J. (2012). A global singlesensor analysis of 2002-2011 tropospheric nitrogen dioxide trends observed from space. Journal of $\mathrm{Ge}$ ophysical Research: Atmospheres, 117 (D16).

Sen, P. K. (1968). Estimates of the regression coefficient based on Kendall's tau. Journal of the American statistical association, 63(324), 1379-1389.

Van Der A, R. J., Eskes, H. J., Boersma, K. F., Van Noije, T. P. C., Van Roozendael, M., De Smedt, I., Peters D. H. M. U. \& Meijer, E. W. (2008). Trends, seasonal variability and dominant $\mathrm{NOx}$ source derived from a ten year record of $\mathrm{NO}_{2}$ measured from space. Journal of Geophysical Research: Atmospheres, 113(D4).

WRI. (2019). World Resources Institute, Global Power Plant Database, http://datasets.wri.org/dataset/ globalpowerplantdatabase, last access (December 2019)

Xiao, Z., Jiang, H., Song, X., \& Zhang, X. (2013). Monitoring of atmospheric nitrogen dioxide using Ozone Monitoring Instrument remote sensing data. Journal of Applied Remote Sensing, 7(1), 073534. 